\title{
Covid-19 and Cricket: Playing with the Contagion and/of Caste ${ }^{1}$
}

Shruti Sharma is a doctoral candidate with CSSSC, Kolkata. Her research interests include Critical geography and gendering of sports.

Out of all the team sports that are played and watched in India, cricket seems to be the one sport that can easily adjust to the 'new' normal unleashed by the outbreak of novel coronavirus. The nature of the game lends itself to physical and social distancing norms. Through this commentary, I question the newness of distancing norms in the everyday lives of people through the conundrum faced by the international cricketing fraternity (rule makers, players and administrators) regarding the inconveniences to play the game in the times of Covid-19, particularly with regard to the usage of saliva to shine the cricket ball. This piece attempts a suturing together of socio-spatial relations that seem to be sundered by Covid-19 but have a deeper ideological anchor in the hierarchical and discriminatory system of caste in the Indian context.

For the batters, the helmet and gloves can become symbolic of protection not just from being injured by the pace of a bowled ball but also from transmitting or contracting the virus if they happen to come physically close to another player on-field. This physical closeness usually occurs while discussions with the batting partner, if two players mistakenly run into each other or if a brawl with a (male) player from the opposition takes place. However, for social purposes like celebrating a century or a victory, the two symbolic objects that enforce distancethe helmet and gloves - will not suffice, and they have to be avoided at all costs. In case of the fielders/bowlers, although they can easily avoid coming physically close to each other-for social purposes like celebrating a wicket through hugs, and maintain a safe distance while strategizing - the object of contention becomes the ball itself, which

${ }^{1}$ A version of this commentary has been published online under "Voices from the Field - Commentary \& Opinion" in Critical Asian Studies on July 13, 2020. 


\section{6 / Shruti Sharma}

Salesian Journal of Humanities and Social Sciences, Vol. XI, No.1 (May 2020)

ISSN: 0976-1861 |DOI: 10.51818/SJHSS.11.2020.85-90 | Page: 85-90,

Section: Articles

is the prime equipment for play. All the space within the boundary is occupied through the medium of the ball - the bowler running their run up with the ball in a hand, the bounce of the ball on the pitch, the willow striking the ball directing it on the field, and the fielders set in motion to collect/catch and throw the ball back to one of the two ends of the pitch where a teammate is stationed.

With the primacy of the ball, the main contention one would imagine is the frequent touching of the ball by players on the fielding side. But that is not it. There is another layer to the touch of the ball-a shiny yet rough layer - which comes to be with the usage of saliva on it. To begin the play of international tournaments amidst the uncertainty of the pandemic, the International Cricket Council's Cricket Committee "unanimously agreed to recommend that the use of saliva to polish the ball be prohibited" because of the "elevated risk of the transmission of the virus through saliva", although they found "no need to prohibit the use of sweat to polish the ball" as it is "highly unlikely that the virus can be transmitted through sweat." 2 The fear of the ball becoming an object or material through which the infection of the virus can be carried and transmitted - a fomite - seems to be addressed by the new regulations.

Soon, we will see cricket being telecast on television without stadium spectators. Here, the reference is particularly to men's cricket since women's cricket is nowhere close to being considered a spectacle. The ball - though protected from being a fomite-continues to flourish as an object in and through which discriminatory social relations and castebased norms are concealed and transmitted. Saliva is used to shine one of the two sides of a cricket ball made from the "middle back parts of best cow hides" ${ }^{3}$ which is divided by a seam sewn by wild boar bristles. The leather ball wears and tears over the duration of play, and so the strategy behind shining one side of the ball is to keep it in a condition where the ball's movement can be manipulated/controlled. As the

\footnotetext{
2 "Cricket Committee recommends prohibition of saliva to shine the ball" (Press Release), International Cricket Council, accessed July 7, 2020, https:/ / www.icc-cricket. com/media-releases/1670371.
}

3 “The "Oriental” Cricket Balls" (Advertisement), The Times of India, April 13, 1904. 
bowled ball moves through the air, the rough side causes friction, whereas it moves swiftly through the polished side, having an effect on the swing/movement of the ball. Through applying saliva and rubbing the wetness off on the trousers, one side of the ball is nurtured or maintained just as the other side is let to be rough and old. Hence, over the course of play, the ball ends up having a rough/old side and a shiny/new side.

Interestingly, the two sides of the ball divided by a seam also becomes a metaphor for the simultaneous embedding in and distancing from the social (norms and relations) concealed in the ball in its commodified form. The shiny side-nurtured and maintained - becomes symbolic of the aesthetic spectacle that cricket is within the stadium and telecasted on television. This aesthetic is that of play fused with nationalist fervour. The seam becomes symbolic of the boundary that separates the spectacle of play from the rough/old tattered side of the ball. This rough side of the ball becomes a signifier of the spaces where cricket is producedsocially, spatially and temporally distant from the aesthetic site of play.

The two spaces - of production and play - and the multi-sited lives and social relations amongst them, are deeply interlinked through the medium of the ball. It is the ball that moves through the touch of various

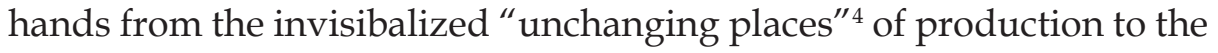
aesthetic and conceptually dynamic spaces of the play. From the rearing of cattle in the countryside, slaughtering one in an abattoir or collecting the carcass, flaying the skin off it, tanning the hide in a tannery, handsewing the hide with wild boar bristles in a factory/stitching centre/ home, transporting the object in its various forms (within and across national boundaries) to finally consuming it for practice and play as a cricket ball in a stadium/club/home; the object traverses through gradations that manifest materially in the spatial division of locations and as Ambedkar had enunciated in the seminal Annihilation of Caste-

${ }^{4}$ Gopal Guru, "Aesthetic of Touch and the Skin: An Essay in Contemporary Indian Political Phenomenology", in Arindam Chakrabarti (ed.) The Bloomsbury Research Handbook of Indian Aesthetics and the Philosophy of Art, (New York: Bloomsbury Academic, 2016), 301. 


\section{8 / Shruti Sharma}

Salesian Journal of Humanities and Social Sciences, Vol. XI, No.1 (May 2020)

ISSN: 0976-1861 |DOI: 10.51818/SJHSS.11.2020.85-90 | Page: 85-90,

Section: Articles

social "division of labourers."

Implicated in the spatiality are Brahmanical social relations and norms of caste based on practicing ritually ordained distance through the ideology of purity and pollution. "Remember, leather - as the carrier of the ideology of purity-pollution - has been regulating the human touch among the Indians, ${ }^{5}$ writes Gopal Guru, to bring the double-speak of the touchable castes up front. Leather, specially cow hide, working with it and those who have to work with it are considered polluting to touch to the caste-Hindus. Yet, "the live skin of the leather workers is treated as defiling and disgusting, while the dead skin in the form of leather ball... becomes intimate to the upper-caste body." 6 The intimacy of the upper-caste cricketer, ${ }^{7}$ revered at the top of the ladder of caste, to leather is evident in the licking of cow hide with their 'saliva' to shine/polish one side of the cricket ball - the side which becomes a metaphor for their own polished existence built upon the 'sweat' and labour of those pushed to the bottom of the caste ladder, relegated to the last rung of contempt. The ball can be licked but the leather worker cannot even be touched.

We see how the meaning of an object changes as it traverses a journey from its raw/taboo form to its finished/aesthetic form. Ambedkar would call it a journey-in degrees of ascent-from contempt to reverence, up the ladder of the institution of caste. This ladder of aesthetics - the "moral grammar"8 of which is controlled by the touchable hands - is not just for the social object that the ball is but also of the persons/castes engaged in working/playing with the object at various stages/spaces, their bodies and bodily fluids - saliva and sweat. Hence, we see how through biological and social bodily fluids, the already existing social

${ }^{5}$ Ibid.

${ }^{6} \mathrm{Ibid}, 302$.

${ }^{7}$ See Richard Cashman, Players, Patrons and the Crowd: The Phenomenon of Indian Cricket, (New Delhi: Orient Longman, 1980) for an analysis of the social location of male crickets who have played first class cricket at the domestic and international level in India between 1930 to 1980 .

${ }^{8}$ Guru, 298. 
Covid-19 and Cricket: Playing with the Contagion and/of Caste / 89

Salesian Journal of Humanities and Social Sciences, Vol. XI, No.1 (May 2020)

ISSN: 0976-1861 |DOI: 10.51818/SJHSS.11.2020.85-90 | Page: 85-90,

Section: Articles

and physical distancing norms that emanate from the Brahmanical ideology of purity-pollution are being reinforced in the realm of sport; wherein the spectacle that playing the game is within the stadium conceals the fractured social (norms and exclusion) which is deeply imbricated in the discriminatory relations of caste.

The act of putting saliva on cow-hide in the midst of spectators in a field/stadium and being telecast on television, the frame zoomed in, is portrayed as an innocent act-for the sake of the game. Unfortunately, Covid-19 has taken away this innocence from the cricketers as it is now not regulated for them to perform it. However, prior to the question of the ball becoming a fomite and hence, the legality-illegality of the usage of saliva, caste-Hindus had given themselves the moral and social sanction of playing with and licking "the most supreme taboo, a dead cow['s hide]" in the form of the ball. We are all too familiar with such innocence on the part of us caste-Hindus which comes with a doublespeak in spheres we do not think it can. The cricket ball is so omnipresent that it becomes a secular object - to be touched, licked and celebrated.

A persistent defamiliarization with the hegemony of upper caste consciousness needs to be undertaken to locate the manifestations of caste, not just in nooks and corners but also where we do not expect to miss it, right in the centre of (dis)play. This consciousness has clawed like an eagle's so deep into our always already ideological/casteist selves that we do not have the conceptual capability to think of the cricket ball as anything other than the finished form we see it in. Around the aesthetic object for play within the stadium spectacle, social realities of multiple actors involved with the game are concealed and varied illusions - of nationalist unity and victory - manufactured.

${ }^{9}$ Vijay Prashad, Untouchable Freedom: A Social History of a Dalit Community, (New Delhi: Oxford University Press, 2000), 28. 


\section{0 / Shruti Sharma}

Salesian Journal of Humanities and Social Sciences, Vol. XI, No.1 (May 2020) ISSN: 0976-1861 |DOI: 10.51818/SJHSS.11.2020.85-90 | Page: 85-90,

Section: Articles 